\title{
Perceived Job satisfaction and its impact on Organizational Commitment: An empirical study of public secondary school teachers in Dodoma, Tanzania
}

\author{
Henry Jonathan ${ }^{1}$, Casius Darroux ${ }^{2}$, Jared Massele ${ }^{3}$ \\ 1School of Management, Wuhan University of Technology, China.Research Fellow from Tanzania \\ 2School of Management, Wuhan University of Technology, China.Research Fellow from Commonwealth of \\ Dominica \\ 3School of Management, Wuhan University of Technology, China.Research Fellow from Tanzania
}

\begin{abstract}
This paper cover part of the larger survey undertaken in three public secondary schools in Dodoma, Tanzania abbreviated S1 (urban), S2 (semi-urban) and S3 (rural) as an agreement with respective schools. The study determined general satisfaction, intrinsic satisfaction, extrinsic satisfaction and organizational commitment levels in public secondary school teachers. The relationship between intrinsic satisfaction, extrinsic satisfaction and organizational commitment was explored meanwhile the impact of selected demographic characteristics (age, education and gender) on teachers organizational commitment scores were sorted out as well. Data were collected using self-administered questionnaire and backed up with basic interviews. Results indicated moderate general, intrinsic and extrinsic satisfaction in teachers meanwhile teachers reported very low general organizational commitment. The study also found that there was strong, positive correlation between intrinsic satisfaction and organizational commitment while it revealed medium, positive correlation between extrinsic satisfaction and organizational commitment. It was evident that both intrinsic and extrinsic satisfaction made unique contribution on teachers' organizational commitment variations while intrinsic satisfaction showed strongest contribution. There was no statistically significant difference in teachers' organizational commitment associated with gender, educational level and age groups though younger teachers showed slightly lower commitment than older groups. Implications and strategies for improvement relevant to school managers, educational stakeholders and Government were produced.
\end{abstract}

Keywords-Extrinsic satisfaction, general satisfaction, intrinsic satisfaction, job satisfaction, organizational commitment, Tanzania

\section{Introduction}

Organizational commitment is one among important organizational constructs as it has been proved to drive and determine favorable organizational outcome across sectors. Indeed, several studies have examined the predicting role of intrinsic and extrinsic satisfaction (for instance, [1];[2]; [3]; [4]; [5]), gender ( for example [6]; [7]; [8] and[9]), age (for example [10]; [11]; [12] and [13]) and education ( for example [14]; [15]; [16] and [17]) on organizational commitment. Thus far, it can be noted that significant efforts have been devoted to study predictors of organizational commitment and got published. Despite existence of huge number of studies directed to organizational commitment in the world, few (if any) have been channeled on the organizational commitment in Tanzania. Few studies done in Tanzania to mention here include [18] who investigated level of organizational commitment in secondary school teachers and found teachers' commitment to the teaching profession was devastatingly low. On the other hand [19] examined the impact of transformational leadership dimensions on teachers' organizational commitment and found transformational leadership dimensions had strong effects on teachers' organizational commitment. As it can be seen, these studies creates obvious empirical gap as the focus was on either individual organization commitment as a construct or predictors of organizational commitment other than intrinsic, extrinsic and demographic characteristics.

In practice, it is evident that teachers form an important and crucial part which determines the success or failure of education sector in any nation. Of course, in obvious ways, this is evident because teachers are responsible for maintaining high standards in education, transmission of values and norms to students through effectively teaching them or being relevant models [20]. Yet, for teachers to sufficiently take these responsibilities, strengthening of their commitment in teaching job become of essence [21] Conversely, of late, education reports indicate consistent falling of standards of Tanzanian secondary education for the past five years or so. This is apparent and has been put into overt by National Form Four Examination results. For example, in 2010, 50 percent of the secondary school candidates failed National Form Four Examinations while in 2012, more than 60 percent secondary school candidate failed the same exam [22]. Educational managers and educational stakeholders, including the Tanzanian Government have connected this educational flop with 
generic causes such as inefficient teaching, irresponsible students, inadequate number of teachers and learning infrastructure but little (if any) efforts have been devoted to throw light on the role of teacher's commitment to their job. Consequently, quite too often, the government reacts to educational performance maladies by embarking into traditional strategies for instance, strengthening recruitment efforts which is yet to register desired outcomes. This has been the case due to lack of knowledge of the importance of organizational commitment to educational performance and predictors of organizational commitment in teachers. This study is set to fill this knowledge gap by devoting empirical study aiming at specifically exploring levels of job satisfaction (intrinsic and extrinsic) and organizational commitment in teachers. Then, find out the impact of intrinsic and extrinsic satisfaction on teachers organizational commitment and lastly determine the impact of demographic characteristics (age, gender and education levels) on teachers' organizational commitment in three public secondary schools (namely S1, S2 and S3) in Dodoma, Tanzania. It remains a hope that results of this study will add value on strategies to address gaps in teachers' commitment to their job and impact educational performance.

\subsection{Job satisfaction}

\section{Literature review}

Job satisfaction is the extent to which people like (satisfaction) or dislike (dissatisfaction) their jobs [23]. Suffice it, here to say, Spector suggests job satisfaction is a general or global affective reaction that individuals hold about their current jobs. The importance of job satisfaction specially emerges to surface particularly when an organization start to feel the pinch of negative consequences of job dissatisfaction such as lack of loyalty, increased absenteeism, increase number of accidents etc [24]. As [25] so rightly pointed out, job satisfaction trends can affect labor market behavior and influence work productivity, work effort, employee absenteeism and staff turnover. To quote Williams, previous studies have measured job satisfaction using several job satisfaction dimensions/facets as opposed to global job satisfaction for instance, co-workers, pay, job conditions, supervision, nature of the work and benefits [26]. Later studies, suggest that these facets/dimensions can be merged into two, that is, intrinsic and extrinsic satisfaction ([27]; [28]; [29]). Conceivably, intrinsic satisfaction refers to the job tasks themselves e.g. variety, skill utilization and autonomy while extrinsic satisfaction refers to satisfaction with aspects that have little to do with the job tasks or content of the work itself, such as pay, working conditions and co-workers [30]. Yet, [31] adds more dimension namely general satisfaction which they describe to measure the aggregate of intrinsic and extrinsic satisfaction. To them, intrinsic satisfaction items include ability utilization, achievement, activity, authority, creativity, independence, moral values, responsibility, security, social service, social status and variety. Extrinsic satisfaction items include advancement, company policies, compensation, recognition, supervision-human relations and supervisiontechnical. The general satisfaction adds two items (co-workers and working conditions) on the sum of intrinsic and extrinsic satisfaction making a total of 20 items.

\subsection{Organizational commitment}

Organizational commitment is one of the popular attitudinal variables in the work domain which reflects the extent to which one identifies with and is involved in an organization [32]. Meyer and Allen established that organizational commitment is a psychological state that first; characterizes the employee's relationships with the organization and second; has implications for the decision to continue membership in the organization [33]. By this token, organizational commitment is viewed as a psychological connection that individuals have with their organization, characterized by strong identification with the organization and a desire to contribute to the accomplishment of organizational goals [34]. Relevant to the study at hand, preceding studies found organizational commitment may be impacted by personal characteristics and job related factors ([35]; [36]). Says, [37], Personal or rather demographic characteristics have been one of the most commonly tested antecedents of organizational commitment and includes features like age, gender, education level, marital status, tenure and family responsibilities. Nevertheless, this study opted the impact of demographic characteristics like age, gender and education level on teachers' commitment. On the other hand, job related factors also has been said to influence organizational commitment and by definition it has been said to refer practices used by the employer to assist the employee to understand the job or work role [38]. As for this study, the impact of factors like intrinsic and extrinsic satisfaction as indicated by [39] was taken into consideration.

\subsection{Job Satisfaction as a predictor of organizational commitment}

[40] Determined the impact of teachers' satisfaction with job dimensions (ie. work-itself, quality of supervision and pay) on perceived organizational commitment in public sector universities of Pakistan. Findings of the study proposed that job satisfaction had significant positive influence on organizational commitment of faculty members indicating that deliberated measures on the provision of required intrinsic and extrinsic reward make existing work force satisfied and committed in Universities. Still, [41] investigated the relationship among 
job satisfaction, organizational commitment and turnover intention to determine statistically significant relations. The results supported the set hypotheses in that Job Satisfaction (among other results) had a significant and positive relationship with three dimensions of organizational commitment (ie affective, normative and continuance commitment) suggesting that higher levels in job satisfaction stimulates employees commitment to the current employing organization. However, in another study, [42] empirically examined the extent to which job satisfaction correlate with organizational commitment focusing on bank employees specifically and private sector generally. They hypothesized that; job satisfaction (company policy, salary, working condition, interpersonal relation and advancement) had a significant impact to organizational commitment among bank employees, proposing improvement in job satisfaction factors strengthen employees' commitment to their organization. Yet, a study by [43] tested the relationships among job satisfaction, organizational commitment and turnover intention using hypotheses "Job satisfaction is related to affective, normative and continuance commitment of employee". Results indicated that job satisfaction was one of the most antecedents of organizational commitment and suggested that high levels of job satisfaction results in higher commitment [44]. In other words, it indicated that job satisfaction positively influences on affective commitment, continuance commitment, and normative commitment. Consistently, preceding studies claim positive relationship between job satisfaction and organizational commitment across sectors. Such relationship brings us into conclusion that up scale of one construct (among job satisfaction and organizational commitment), influence better condition on the other and thus positive relationship between the two constructs. .

\subsection{Intrinsic and extrinsic satisfaction}

\section{Hypotheses development}

As it has been said earlier, most studies propose positive relationship between components of job satisfaction on organizational commitment. For instance, [45] asserted that employees, who are satisfied with intrinsic and extrinsic job factors, display strong organizational commitment claiming positive relationship between variables. Supporting earlier studies, [46], established that intrinsic and extrinsic satisfaction had significant effect on affective and normative commitment but not on continuance commitment. However, [47] suggested that all elements of job satisfaction (extrinsic, intrinsic and general satisfaction) had been found to significantly relate to organizational commitment. Again, [48] found significant and positive effect of both components of job satisfaction on organizational commitment. In another study, [49] Intrinsic job satisfaction, extrinsic job satisfaction, and overall job satisfaction were found to be significantly and highly related with organizational commitment, an indication that promoting job satisfaction elements (eg intrinsic, extrinsic and general satisfaction) improves employees' commitment to the organization. It should be deduced from this juncture that there are consistent understanding on the relationship between job satisfactions factors (intrinsic and extrinsic) though conflicting results on prediction level (intrinsic and extrinsic on organizational commitment). Therefore we propose the following three hypotheses

H1: There is a significant and positive impact of high intrinsic satisfaction on organizational commitment

$\mathrm{H} 2$ : There is a significant and positive impact of high extrinsic satisfaction on organizational commitment

\subsection{Gender and organizational commitment}

As the participation rate of women in the workforce has increased, there has been an emphasis in organizational research on the impact of sex in organizational constructs [51]. However, results have ever been mixed and in some cases counter each other. For example, [52] indicated that female employees had higher levels of continuance commitment than men suggesting gender differences on perceived organizational commitment dimensions. Likewise, female respondents demonstrated a statistically significant higher level of Organizational Commitment than did their male counterparts [53]. Conversely, in another study, results revealed that there was no significant gender difference in organizational continuance and normative commitment but noted a statistical tendency of differences in affective commitment between men and women showing men are more affectively committed than women [54]. Again, differences have been noted between men and women for organizational commitment in that, men had significantly higher scores on continuance and normative commitment as compared to female counterpart [55] advocating gender differences in organizational commitment scores. To this point, it is evident that there are conflicting results when sex is taken into consideration and therefore we propose.

H3: There is difference in organizational commitment between male and female teachers.

\subsection{Age and organizational commitment}

There is confirmation that older employees perceive and interpret job/organizational-related events and experiences differently from younger counterpart which in turn uncover reports of job/organizational attitudes that vary across age groups [56]. Recently, [57] found different age group $(<25,26-35,36-45$ and $>45)$ of employees differ in perceived organizational commitment indicating age group difference in staff commitment 
to the organization. Although some age group indeed reported being more committed to the organization, such report do not necessarily correspond to more favorable everyday organizational experiences [58]. For instance, [59] reported no significant difference was found among different age groups of employees concerning their organizational commitment proposing no matter what age employees hold, it make no difference in their commitment to the organization they are working. We therefore suggest hypothesis

H4: There is difference in organizational commitment between old, middle aged and younger teachers.

\subsection{Education and organizational commitment}

Level of education is another demographic factor that has been related to organizational commitment [60]. [61] found variation of perceived organizational commitment in an organization with different levels of education. In addition, it has been noted that the higher educated employee groups are more committed groups than the lower educated employee groups [62] indicating the increase in employee education levels, employees' commitment to their organizations becomes more and more strong. [63] suggest that, employees who maintain good educational background are more likely to be committed to the organization and stay with a firm than younger employees proposing positive relation in that the more educated employee become, the more committed become to the organization. We therefore propose hypothesis

H5: There is difference in organizational commitment between non degree and degree holder teachers.

\subsection{Sample, data and ethical issues}

\section{Methods}

This study was conducted as part of a large survey conducted in three public secondary schools in Dodoma, Tanzania abbreviated S1 (urban), S2 (semi-urban) and S3 (rural). Researchers and schools agreed in principal that school names shall not appear in publications of any nature but abbreviations (in this case S1, S2 and S3 were opted). Prior administration of survey questionnaire, ethical issues was sufficiently settled. This included seeking permission to use Minnesota Satisfaction Questionnaire (MSQ) which was granted by Vocational Psychology Research - University of Minnesota. Hitherto, Application letters accompanied by a sample questionnaire for this study was sent to each participating school selected in the study (abbreviated S1, S2 and S3) for permission consideration and go ahead secured in time. School selection was purposive aiming to have mixture of rural (S3), urban (S1) and semi-urban (S2) schools. Therefore, data for the study was purposively obtained from three public secondary schools (S1, S2 and S3) survey in Dodoma region pending poor performance of the region in National Form Four Exams [64]. An assessment of whether or not the scales measures what it was supposed to measure was done by submitting scale instrument to Human Resource experts in Local Government Training Institute (Research, Consultancy and Short course department) Dodoma, Tanzania. Independently, three experts granted their validation and few recommendations that focused on modifying some words. All teachers in three schools were invited (using key informant in each school) to participate in the study using "instant invite and questionnaire take" technique. 117 questionnaires ( 70 for S1, 22 for S2 and 25 for S3) were accepted by potential respondents creating a final sample of 117 teachers out of 127 aggregate number of teachers in the three schools under the study. The response rate was $88 \%$ of the respondents following return of 103 filled questionnaires. Face to face interview with head teachers of the three schools was also done in the course of seeking specific clarifications relevant to the study.

\subsection{Measures}

\subsubsection{Intrinsic and extrinsic satisfaction}

To measure intrinsic and extrinsic satisfaction as independent variables, the original instrument ie Minnesota Satisfaction Questionnaire (MSQ) short form developed by [65] was used. The choice of MSQ short form was based on two major reasons. First, it is feasible to obtain a more individualized picture of worker satisfaction than a more general measure of satisfaction with the job as a whole [70]. Second, it is relatively not too long to affect response rate [71]. Respondents rated their level of agreement with 20 statements (12 for intrinsic, 6 for extrinsic plus 2 for general satisfaction) on a 5-Likert scale starting from $1=$ strongly disagree to $5=$ strongly agree. It has been noted before that job satisfaction scales had good internal consistency, Cronbach alpha coefficient reported for the Intrinsic Satisfaction scale, ranged from .84 (for the two assembler groups) to .91 for engineers [72]. As per Weiss, Extrinsic Satisfaction scale, the coefficients varied from .77 (for electronics assemblers) to .82 (for engineers and machinists). On the General Satisfaction scale, the coefficients varied from .87 (for assemblers) to .92 (for engineers). The study at hand had cronbach alpha coefficients of .767 for intrinsic satisfaction, .721 for extrinsic satisfaction and .843 for general job satisfaction all of them being greater than .70 suggesting good internal consistency [73] 


\subsubsection{Organizational commitment}

To measure organizational commitment as dependent variable to the study, the instrument ie Organizational Commitment Questionnaire (OCQ) developed by [74] was used. Meyer and Allen's scale measured affective, normative and continuance commitment. Originally, the OCQ had 8 scales in each scale category (affective, normative and continuance) but was reduced to 6 items in each [75]; [76]). Items 3, 4 and 6 (affective) and 1 (normative) got reverse score to avoid bias response. The study went for OCQ because organizational commitment is multi-dimensional construct and it needed instrument that could capture this in terms of affective, normative and continuance commitment [77]. [78] Reported Cronbach alpha coefficient of .87 for affective, .75 for continuance, .79 for normative and .80 for alpha of the questionnaire in general. In this study, Cronbach alpha coefficient was .766 for affective, .70 for normative, .751 for continuance and 0.846 for alpha of general scale which is significantly greater than .70 and according to [79], indicated good internal consistency. Respondents were subjected to rate their perceptions on 5- likert scale ranging from $1=$ strongly disagree to $5=$ strongly agree.

\subsection{Data analysis}

Collected data were subjected into SPSS version 19 for quantitative analysis. Prior actual data analysis, preliminary analyses were done to make sure no violation of basic assumptions like normality, linearity, homoscedasticity and multicollinearity. Mean standard deviation and percentages were calculated to show levels of teachers' job satisfaction (intrinsic extrinsic and general satisfaction) and organizational commitment. To determine whether there was significant and positive impact of high intrinsic and extrinsic satisfaction on organizational commitment, Pearson product-moment correlation coefficient analysis and Standard multiple regression analysis was conducted. Also, to find out if there were differences in organizational commitment scores based on gender and educational levels, independent-sample t-test was run. Again, to find out if there were differences in organizational commitment scores based on age differences, one-way between-groups analysis of variance was conducted. Mean interpretations, adopted [80] interpretative scale in that mean scores 1.5 or less $=$ strongly disagree (very low), 1.51-2.50 = Disagree (low), 2.51-3.49 $=$ Neutral/Moderate/Medium, 3.50-4.49 = Agree (high) and 4.5 or greater $=$ Strongly Agree (very high). Correlation output adopted interpretative scale proposed by [81] which suggested $r=0.1$ to 0.29 (small correlation), $r=0.30$ t0 0.49 (medium correlation) and $\mathrm{r}=0.50$ to 1.0 (large correlation). The effect size measured by eta squared was interpreted according to again [82] who proposed output 0.01 =small effect, $0.06=$ moderate effect and $0.14=$ large effect

\subsection{Respondents profile}

\section{Results and discussions}

More than half of the respondents' were female teachers (53.4\%) and the rest were males (46.6\%). Of all respondents, $56.3 \%$ worked in teaching profession for $\geq 10$ years while $43.7 \%$ worked for $\leq 10$ years. Married teachers represented $66 \%$ and most of the teachers had education level of at least first degree $(54.4 \%)$ and other teachers had at most diploma in education. Study sample was dominated by teachers aged $\geq 35$ years $(50.5 \%)$, followed by age range between $35-40$ years $(31.1 \%)$ and $\leq 40$ years $(18.4 \%)$. With regard to location, $59.2 \%$ of the respondents were working in urban area and 19.4 were working in semi-urban areas while $21.4 \%$ were working in rural area.

Table 1: Sample characteristics

\begin{tabular}{lcc}
\hline Characteristics & No. of teachers & Percentage \\
\hline Sex & 48 & 46.6 \\
Male & 55 & 53.4 \\
Female & & \\
Age & 52 & 50.5 \\
$\geq 35$ & 32 & 31.1 \\
$35-40$ & 19 & 18.4 \\
$\leq 40$ & & \\
Marital status & 68 & 66.0 \\
Married & 35 & 34.0 \\
Not married & & \\
Education level & 47 & 45.6 \\
Non degree & 56 & 54.4 \\
At least a degree & & \\
Teaching experience & &
\end{tabular}




$\begin{array}{lll}\geq 10 & 58 & 56.3 \\ \leq 10 & 45 & 43.7 \\ \text { Location } & & \\ \text { Urban } & 61 & 59.2 \\ \text { Semi-urban } & 20 & 19.4 \\ \text { Rural } & 22 & 21.4 \\ \text { School } & & \\ \text { SI } & 61 & 59.2 \\ \text { S2 } & 20 & 19.4 \\ \text { S3 } & 22 & 21.4\end{array}$

\subsection{Job satisfaction and organizational commitment levels}

Results in Table 2 indicated teachers had moderate general job satisfaction (Mean $=2.579)$, intrinsic satisfaction (Mean $=2.522$ ), and extrinsic satisfaction (Mean2.600). Nevertheless, teachers displayed low commitment in their job (Mean $=1.925561)$. For that matter, results endorse what [83] concluded as teachers' commitment on teaching profession in Tanzania is devastatingly low. The nature of this results reflects interview done with headmasters of the three schools who admitted that teachers have long unresolved concerns pertaining to inadequate salaries, poor working conditions and unpaid dues like leave and transfer allowances. Allowing teachers concerns and dissatisfactions to go unresolved for long, might have contributed to these construct levels.

Table 2: Job satisfaction and organizational commitment levels

\begin{tabular}{|c|c|c|c|c|c|c|}
\hline \multicolumn{3}{|c|}{ JOB SATISFACTION } & \multicolumn{3}{|c|}{ ORGANIZATIONAL COMMIT } & \multirow[b]{2}{*}{ J SD } \\
\hline SCALE & & MEAN & SD & SCALE & MEAN & \\
\hline \multicolumn{7}{|l|}{ Intrinsic } \\
\hline Q1 JS & & 4.3883 & .62986 & Q1 AC & 1.3398 . & .53419 \\
\hline Q2 JS & & 1.6990 & .79007 & Q2 AC & 1.3010 . & .57454 \\
\hline Q3 JS & & 3.5243 & 1.19513 & Q3 AC & 1.6408 . & .82669 \\
\hline Q5 JS & & 2.0000 & 1.08465 & Q4 AC & 1.6990 . & .89481 \\
\hline Q9 JS & & 1.3107 & .54285 & Q5 AC & 1.4854 . & .68405 \\
\hline Q10 JS & & 4.2913 & .65126 & Q6 AC & 1.7573 . & .91251 \\
\hline Q11 JS & & 4.2524 & .63737 & Q1 NC & 1.8738 . & .80049 \\
\hline Q13 JS & & 1.9612 & 1.01867 & Q2 NC & 1.3883 . & .50938 \\
\hline Q14 JS & & 1.3786 & .57933 & Q3 NC & 1.3301 . & .63227 \\
\hline Q15 JS & & 1.8738 & .95671 & Q4 NC & 1.4660 . & .80215 \\
\hline Q16 JS & & 1.6699 & .73282 & Q5 NC & 1.3010 . & .57454 \\
\hline Q19 JS & & 1.9126 & .90864 & Q6 NC & 1.3592 . & .62394 \\
\hline Mean & & \multicolumn{2}{|l|}{2.521842} & Q1 CC & 3.8058 & 1.07611 \\
\hline \multicolumn{2}{|l|}{ Extrinsic } & & & Q2 CC & 2.7670 & 1.59167 \\
\hline Q4 JS & 2.4369 & 1.27318 & & Q3 CC & 1.4272 . & .61996 \\
\hline Q6 JS & 1.5728 & .66571 & & Q4 CC & 3.3495 & 1.39121 \\
\hline Q7 JS & 1.2233 & .44130 & & Q5 CC & 3.7767 & 1.38573 \\
\hline Q12 JS & 1.9709 & .91240 & & Q6 CC & 1.5922 . & .85677 \\
\hline Q17 JS & 4.1942 & .70096 & & Mean & 1.925561 & \\
\hline Q18 JS & 4.2039 & .69111 & & & & \\
\hline Mean & 2.600333 & & & & & \\
\hline \\
\hline \multicolumn{7}{|c|}{$\begin{array}{l}\text { General } \\
\text { Q8 JS } 4.0583\end{array}$} \\
\hline Q20 JS & \multicolumn{6}{|l|}{$\begin{array}{l}4.0505 \\
1.6699\end{array}$} \\
\hline Mean & \multicolumn{6}{|c|}{2.579615} \\
\hline
\end{tabular}

\subsection{Correlation and regression results}

\subsubsection{Correlation results}

Pearson product - moment correlation coefficient results (Table 3 ) indicated there was strong, positive correlation between total intrinsic satisfaction and total organizational commitment $[r=.605, n=103, p<0.05]$ and that, there was medium, positive correlation between total extrinsic satisfaction and total organizational 
commitment $[\mathrm{r}=.494, \mathrm{n}=103, \mathrm{p}<0.05]$ with high levels of perceived intrinsic and extrinsic satisfaction associated with higher levels of perceived organizational commitment. Thus far, results are in line with proposed hypotheses which mean $\mathrm{H} 1$ and $\mathrm{H} 2$ were supported. This report endorses previous studies that concluded intrinsic and extrinsic satisfaction had significant and positive impact on organizational commitment (eg [84]; [85]; [86]; [87]). It is indicated by this study that teachers become committed with their job when they are satisfied with both intrinsic and extrinsic rewards. In other words, if intrinsic and extrinsic rewards mismatch teachers' interest and needs, teachers' commitment becomes low.

Table 3: Correlation results

\begin{tabular}{llllll}
\hline S/N & Variables & 1 & 2 & 3 & \\
\hline 1 & Intrinsic satisfaction & 1 & & \\
2 & Extrinsic satisfaction & $.576^{* *}$ & 1 & & \\
3 & Orgn commitment & $.605^{* *}$ & $.494^{* *}$ & 1 \\
& $* * \mathrm{P}<0.01$ & & &
\end{tabular}

\subsubsection{Regression results}

Standard multiple regression results in Table 4, showed the study model was statistically significant (F $=32.998, \mathrm{p}<0.05)$. Intrinsic and extrinsic satisfaction explained $39.8 \%$ variance in the dependent variable $(\mathrm{R} 2$ $=.398)$ which is relatively respectable percentage. Still, intrinsic satisfaction (Beta $=.479)$ and extrinsic satisfaction (Beta $=.218)$ indicated statistically significant and positive contribution $(\mathrm{p}<0.05)$ while intrinsic satisfaction indicating stronger impact. It is indicated by this results that teachers feel commitment to their job and schools due to reasons including intrinsic and extrinsic satisfaction. Further, teachers become less committed when they perceive poor intrinsic and extrinsic reward embedded in their job.

Table 4: Regression Results

\begin{tabular}{|c|c|c|}
\hline Predictors & Beta & Sig. \\
\hline Intrinsic satisfaction & 0.479 & 0.000 \\
\hline Extrinsic satisfaction & 0.218 & 0.024 \\
\hline 0.398 & & \\
\hline Adjusted R2 & & \\
\hline 32.998 & & \\
\hline
\end{tabular}

Dependent variable: Organizational Commitment

\subsection{Independent-sample t-test results}

\subsubsection{Gender}

An independent - samples t-test was conducted to compare the organizational commitment for male and female teachers (Table 5). There was no significant difference in scores for males $(\mathrm{M}=35.7292, \mathrm{SD}=9.04302)$ and females $[\mathrm{M}=33.7273, \mathrm{SD}=8.09539 ; \mathrm{t}(101)=1.185, \mathrm{p}=.239]$. The magnitude of the differences in the means was eta $=0.014$ which by Cohen 1988 had small effect. Results went contrary to proposed hypotheses and as a result H3 was not supported. The results are in line with studies like [88] which concluded no significant difference in organizational commitment levels associated with gender. Indication is drawn from this study is that commitment quest has nothing to do with a teacher being male or female. Associated reasons for the result would probably be similar nature of work teachers face and similar working environment teachers' work upon.

Table 5: Analysis of Variance for Intention to Leave by Gender 


\begin{tabular}{llllllllll}
\hline SEX & $\mathrm{N}$ & MEAN & SD & F & Sig. & Sig.2-T & t & Eta & df \\
\hline Male & 48 & 35.7292 & 9.04302 & 3.040 & .084 & .239 & 1.185 & 0.014 & 101
\end{tabular}

Female $\quad 55 \quad 33.7273 \quad 8.09539$

\subsubsection{Education}

An independent - samples t-test was conducted to compare the organizational commitment for non-degree and degree holder teachers (Table 6). There was no significant difference in scores for non-degree teachers $(\mathrm{M}=33.0851, \mathrm{SD}=6.29296)$ and degree holder teachers $[\mathrm{M}=35.9821, \mathrm{SD}=9.95359 ; \mathrm{t}(94.292)=-1.793, \mathrm{p}=0.076]$. The magnitude of the differences was eta $=0.03$ which according to Cohen (1988) had small effect. Hence, H5 was rejected. Indeed, results counter huge studies that proposed differences in organizational commitment levels associated with educational level ([89]; [90]; [91]; [92]). It is suggested by this result that difference in teachers organizational commitment is contributed by demographic factors and educational levels is not among them. The primary reasons could be that teachers share common needs and interests when it comes to commitment which responsible persons and institutions have not captured.

Table 6: Analysis of Variance for Intention to Leave by Education

\begin{tabular}{lccccccccc}
\hline SEX & N & MEAN & SD & F & Sig. & Sig.2-T & t & Eta & df \\
\hline $\begin{array}{l}\text { Non } \\
\text { Degree }\end{array}$ & 47 & 33.0851 & 6.29296 & 11.197 & .001 & .076 & -.1 .793 & 0.03 & 94.292 \\
Degree & 56 & 35.9821 & 9.95351 & & & & & & \\
\end{tabular}

\subsection{ANOVA results}

\subsubsection{Age}

A one-way between-groups analysis of variance results (Table 7) indicated a statistically significant difference at $\mathrm{p}<0.05$ level in organizational commitment scores for the three age groups $[\mathrm{F}(2,100)=49.466$, $\mathrm{p}=0.000]$. Despite reaching statistical significance, the actual difference in mean scores between the groups $(\geq 35$ years, $35-40$ years and $\leq 40$ years) was 0.497 which according to Cohen (1988) is classified as small effect size. Post- hoc comparisons using the Tukey HSD test indicated that the mean scores differed across the three groups ie group 1- $\geq 35$ years $(\mathrm{M}=29.2115, \mathrm{SD}=4.47799)$, group 2-35-40 years $(\mathrm{M}=37.5625, \mathrm{SD}=7.79966)$ and group 3$\leq 40$ years $(\mathrm{M}=44.6842, \mathrm{SD}=6.88842)$. Consequently, $\mathrm{H} 5$ was rejected. Study results are in congruence with the likes of [93] who asserted no matter what age one possess, it make no difference in the commitment to the job. The study indicated that teachers' commitment difference is contributed by other demographic factors and not age groups. The reasons for insignificant difference could be negligence in addressing teachers' interests and needs on commitment common to all age groups.

Table 7: Analysis of Variance for Intention to Leave by Age

\begin{tabular}{llllllll}
\hline \multicolumn{1}{c}{$\begin{array}{c}\text { Sum of } \\
\text { squares }\end{array}$} & $\begin{array}{l}\text { Mean } \\
\text { df }\end{array}$ & squares & F & Sig. & Eta \\
\hline $\begin{array}{lllllll}\text { Between } \\
\text { Groups }\end{array}$ & 3722.453 & 2 & 1861.227 & & 49.466 & 0.000 & 0.497 \\
Within & & & & & & \\
Groups & 3762.653 & 100 & 37.627 & & & \\
Total & 7485.107 & 102 & & & & \\
\hline
\end{tabular}

\subsection{Conclusions}

\section{Conclusions, implications and limitations}

This study had four specific objectives to address and at this juncture all of them have been carefully investigated. The first specific objective was to determine job satisfaction (general, intrinsic and extrinsic satisfaction) and organizational commitment levels in public secondary school teachers. General job satisfaction $(M=2.579)$, intrinsic satisfaction $(M=2.522)$, and extrinsic satisfaction $(M=2.600)$ were found to be moderate 
in public secondary school teachers. However, general organizational commitment was found to be very low. The second specific objective was geared to find out the relationship of job satisfaction dimensions (intrinsic and extrinsic satisfaction) and organizational commitment. Correlation analysis revealed strong, positive correlation between intrinsic satisfaction and organizational commitment while it revealed medium, positive correlation between extrinsic satisfaction and organizational commitment. That means the increase in intrinsic and extrinsic satisfaction results in commitment increase as well. On the third specific objective, the essence was to explore the impact of intrinsic and extrinsic satisfaction on teachers' organizational commitment. Regression analysis shown both intrinsic and extrinsic satisfaction made unique contribution on teachers organizational commitment variations while intrinsic satisfaction showing strongest contribution. With respect to objective four, the aim was to compare organizational commitment scores based on gender, education and age differences. There was no statistically significant difference in teachers' organizational commitment associated with gender, educational level and age groups though younger teachers showed slightly lower commitment than older groups. Though intrinsic satisfaction showed stronger contribution in teachers' organizational commitment, it is recommended that extrinsic satisfaction should also be taken into consideration in an attempt to intervene teachers' commitment.

\subsection{Implications}

The findings from this study have great implications for programmes that might improve teachers' commitment to teaching profession and schools. This is the case because the study highlighted the importance of intrinsic satisfaction, extrinsic satisfaction and demographic characteristics on teachers' organizational commitment. For that reason, some implications are uncovered here for improvement purposes.

First, general job satisfaction was found to be moderate and organizational commitment was found to be low in teachers which of course, need some remarkable improvement. With moderate job satisfaction and low commitment, it is pretty straight forward that doors are open in teachers for other careers as well. It suggests that teachers are still searching and yet to decide what will be their career in future. As an implication, decision on a choice of work in life or for a given period of time may prevent organizational commitment [94]. School administrators, government and other stakeholders should identify predictors of job satisfaction and facilitate them in time for teachers to positively decide on teaching profession, thereby fostering their commitment in time. Second, Given that teachers were moderately satisfied with intrinsic factors and yet it made significant unique positive contribution on teachers' organizational commitment; the government, educational stakeholders and administrators should consider re-designing teaching work itself. Such redesigning should take into account intrinsic factors such as achievement, creativity, authority, security, responsibility, social service, social status and variety which according to the results they received very strongly disagreement rating (very low satisfaction). Quoting [95], job enrichment may be useful to increase the employee's freedom, independence, responsibility and authority which in turn increase job satisfaction. It should be expected that, if intrinsic is properly and timely improved among teachers, commitment will also be improved because teachers will perceive teaching as an occupation to plan long term career with. Third, given that teachers were moderately satisfied with extrinsic factors and yet extrinsic satisfaction made significant unique positive contribution on teachers' organizational commitment; the government, educational stakeholders and administrators should consider to review teacher compensation structure and teacher development progrmmes. Of course, in obvious ways, factors such as advancement, policies, compensation and recognition which according to the results received very low rating (very low satisfaction), should find a place in improvement interventions. In reviewing, for instance compensation package (monetary), the actual cost of living should be taken into consideration otherwise review will be useless. Says [96], in revising the monetary reward, the cost of living should be taken into account as this will protect employee welfare, increase their purchasing power, and decrease their burdens in fulfilling family and personal needs which in return will invoke their satisfaction and commitment level to the organization. Fourth, analysis of variance revealed no significant differences between organizational commitment levels across gender groups, across age groups and across educational groups. But the organizational commitment is found to be very low indeed. It follows that; the government, educational stakeholders and administrators should put in place job satisfaction factors that will foster intrinsic and extrinsic satisfaction to make teachers commitment relatively better. This could be done by establishing and institutionalizing work condition improvement programmes that foster perceived job satisfaction (intrinsic and extrinsic). For example, the government may opt to strengthen teaching facilities supplies, housing, descent offices etc. As [97] perfectly recommended, job satisfaction (intrinsic and extrinsic) improvement involves provision of necessary facilities, conducive organizational climate and take actions that cater for the welfare of the workers to improve organizational commitment. It should be hoped that proper address of job satisfaction gaps in terms of intrinsic and extrinsic factors, will as well improve commitment in teaching profession and so teaching outcomes.

\subsection{Limitations}


Though carries useful findings on the impact of job satisfaction dimensions on organizational commitment, this study should be read with few limitations. For example, there may be concern on result generalization as the study was conducted in one region (Dodoma) out of more than 26 regions in Tanzania, mainland. Also, social desirability bias concern may creep in as data collection method utilized self-report measures and little of interviews. Again, the study did not employ any moderators and therefore we propose future study to employ them.

\section{References}

[1] O'Reilly, Charles A.; Caldwell, and David F., Job choice: The impact of intrinsic and extrinsic factors on subsequent satisfaction and commitment. Journal of Applied Psychology, 65(5), 1980, 559-565

[2] Gunlu Ebru, Aksarayli Mehmet and Percin Nilufer Sahin (2009), Job satisfaction and organizational commitment of hotel managers in Turkey, International Journal of Contemporary Hospitality Management, 22 (5) 2009, 693-717

[3] Samavi S.A.. Study of Relationship between Job Satisfaction and Organizational Commitment among High-School Managers. Journal of Life Sci. Biomed. 1(1), 2011, 1-3.

[4] Hashmi Maryam Saeed and Naqvi Imran Haider, Investigating Organizational Commitment as the Outcome of Job Satisfaction: A Study of Banking Sector of Pakistan, International Journal of Learning and Development, 2(4), 2012

[5] Raymond Toga and Mjoli Q. Themba (2012).The relationship between job involvement, job satisfaction and organizational commitment among lower-level employees at a motor-car manufacturing company in East London, South Africa

[6] Stewart M. Susan, Mark N. Bing, Melissa L. Gruys and Michael C. Helford, Men, Women, and Perceptions of Work Environments, Organizational Commitment, and Turnover Intentions. Journal of Business and Public Affairs 1 (1), 2007

[7] Clayton Bruce, Stanley Petzall, Barbara Lynch and Julie Margret, an Examination of the Organisational Commitment of Financial Planners, International Review of Business Research Papers, 3(1) 2007, 60 - 72

[8] Labatmediene Lina, Individual correlates of organizational commitment and intention to leave the organization, Baltic Journal of Management, 2 (2), 2007, 196-212

[9] Deprez Jana, Herman Van den Broeck, Eva Cools and Dave Bouckenhoooghe (2012) Gender Differences in Commitment to Change: Impacted By Gender? Working Paper.

[10] Weiss, H. M, and Cropanzano, R.. Affective events theory, A theoretical discussion of the structure, causes, and consequences of affective experiences at work. In B. M. Staw and L. L. Cummings (Eds.), research in organizational behavior, 1996 1-74. Greenwich, CT, JAI Press.

[11] Kanchana, P.N \& Panchanatham,N, “The Influence of Demographic Factors on Organisational Commitment", International Journal of Exclusive Management Research, 2 (5), 2012, 1-13.

[12] Luchman, J. N., Kaplan, S. A., and Dalal, R. S. Getting older and getting happier with work: An information-processing explanation. Social Indicators Research, 108(3), 2012, 535-552.

[13] Anari Nahid Naderi, Teachers: emotional intelligence, job satisfaction, and organizational commitment, Journal of Workplace Learning, 24 (4), 2012, 256-269

[14] Iqbal Adnan. An Empirical Assessment of Demographic Factors, Organizational Ranks and Organizational Commitment, International Journal of Business and Management, 5, (3), 2010, 16-27

[15] Chen, L. T., Chen, C. W., \& Chen, C. Y.. Are educational background and gender moderator variables for leadership, satisfaction and organizational commitment? African Journal of Business Management, 4(2), 2010, 248-261

[16] Bakan İsmail, Tuba Büyükbeşe, and Burcu Erşahan, An Investigation of Organizational Commitment and Education Level among Employees, International Journal of Emerging Sciences, 1(3), 2011, 231-245

[17] Keramatia Mohammad Ali, Mohammad Sadegh Horria and Seyed Hamid Reza Afzalipoorb, A study on effects of personal characteristics on organizational commitment, Management Science Letters 3, 2013, 345-350

[18] Mkumbo A.K.Kitila. Teachers' Commitment to, and Experiences of, the Teaching Profession in Tanzania: Findings of Focus Group Research, International Education Studies 5, (3) 2012, 222-227

[19] Nguni Samuel Sleegers Peter and Denessen Eddie, School Effectiveness and School Improvement: An International Journal of Research, Policy and Practice 4 (1), 2012, 200-219

[20] Oziambo, B. The Contribution of Head Teachers to Curb Teacher Misconduct in Tanzania Public Primary Schools. Masters Diss., Faculty of Education. University of Dar es Salaam, 2010

[21] Mkumbo A.K. Kitila. Teachers' Commitment to, and Experiences of, the Teaching Profession in Tanzania: Findings of Focus Group Research, International Education Studies 5, (3), 2012, 222-227

[22] (a) United Republic of Tanzania (URT) National Examinations Council of Tanzania. (NECTA, 2011). Examination results-Statistics for October 2010 results

[22] (b) United Republic of Tanzania (URT), National Examinations Council of Tanzania. (NECTA, 2013). Examination resultsStatistics for October 2012 results

[23] Spector, P. E. (1997). Job satisfaction: Application, assessment, causes, and consequences. London: Sage.

[24] Aziri B. Job satisfaction: a literature review, Management research and practice 3 (4) 2011, 77-86

[25] Aktaruzzaman, Clement Che Kum, and Hasan Faisal Job satisfaction among teachers of Technical Training Centers (T.T.Cs.) in Bangladesh, 2011

[26] Williams, J.. Job satisfaction and organizational commitment, 2004; found on 02/July 2013 at https://workfamily.sas.upenn.edu/glossary/j/job-satisfaction-definitions

[27] Weiss, D. J., Dawis, R. V., England, G. W., and Lofquist, L. H.. Manual for the Minnesota Satisfaction Questionnaire. Minneapolis: University of Minnesota, 1967

[28] Spector, P. E. Job satisfaction: Application, assessment, causes, and consequences. London: (Sage 1997)

[29] Hirschfeld, R.R.. 'Validity studies. Does revising the intrinsic and extrinsic subscales of the Minnesota Satisfaction Questionnaire Short Form make a difference?'Educational Psychological Measurement, 60, 2000, 255-270.

[30] Buitendach J.H. and Witte H. De, Job insecurity, extrinsic and intrinsic job satisfaction and affective organizational commitment of maintenance workers in a parastatal, S.Afr.J.Bus.Manage. Vol 36(2) 2005, 27-37

[31] Weiss, D. J., Dawis, R. V., England, G. W., and Lofquist, L. H.. Manual for the Minnesota Satisfaction Questionnaire. Minneapolis: University of Minnesota, 1967

[32] Karakurum Müge. The effects of person-organization fit on employee Job satisfaction, performance and organizational Commitment in a Turkish public organization, Doctoral Diss., Unpublished Thesis, Middle East Technical university, 2005 
[33] Meyer, J.P., and Allen, N.J.(1991). A three-component conceptualization of organizational commitment. Human Resource Management Review, 1, pp 61-89

[34] Meyer, J. and Allen, N. Commitment in the Workplace: Theory, Research and Application. London: (Sage 1997)

[35] Steers, R.M., "Antecedents and outcomes of organizational commitment”, Administrative Science Quarterly, Vol. 22, 1977, 46-56.

[36] Mathieu, J.E. and Zajac, D.M., "A review and meta-analysis of the antecedents, correlates, and consequences of organizational commitment", Psychological Bulletin, Vol. 108, 1990, 171-94.

[37] Joiner Therese A. and Bakalis Steve.The antecedents of organizational commitment: the case of Australian casual academics, International Journal of Educational Management, 20 (6), 2006, 439-452

[38] Joiner Therese A. and Bakalis Steve.The antecedents of organizational commitment: the case of Australian casual academics, International Journal of Educational Management, 20 (6), 2006, 439-452

[39] Weiss, D. J., Dawis, R. V., England, G. W., and Lofquist, L. H.. Manual for the Minnesota Satisfaction Questionnaire. Minneapolis: University of Minnesota, 1967

[40] Malik Muhammad Ehsan, Nawab Samina and Naeem Basharat, Job Satisfaction and Organizational Commitment of University, Teachers in Public Sector of Pakistan, International Journal of Business and Management Vol. 5, (6) 2010

[41] Aydogdu Sinem and Asikgil Baris, An Empirical Study of the Relationship Among Job Satisfaction, Organizational Commitment and Turnover Intention, International Review of Management and Marketing, 1, (3), 2011, 43-53

[42] Khamis Kamarul Azman et al. Job satisfaction related with organizational commitment: a study on bank employees at Northern region, Malaysia, Elixir Social Science 48, 2012, 9206-9211

[43] Yücel İlhami, Examining the Relationships among Job Satisfaction, Organizational Commitment, and Turnover Intention: An Empirical Study, International Journal of Business and Management, 7, (20), 2012, 44-58

[44] Yücel İlhami (2012), Examining the Relationships among Job Satisfaction, Organizational Commitment, and Turnover Intention: An Empirical Study, International Journal of Business and Management, 7, (20), 2012, 44-58

[45] O'Reilly, Charles A.; Caldwell, David F., Job choice: The impact of intrinsic and extrinsic factors on subsequent satisfaction and commitment. Journal of Applied Psychology, 65(5), 1980, 559-565

[46] Gunlu Ebru, Aksarayli Mehmet and Percin Nilufer Sahin, Job satisfaction and organizational commitment of hotel managers in Turkey, International Journal of Contemporary Hospitality Management, 22 (5), 2009, 693-717

[47] Samavi S.A. Study of Relationship between Job Satisfaction and Organizational Commitment among High-School Managers. Journal of Life Sci. Biomed. 1(1), 2011, 1-3.

[48] Hashmi Maryam Saeed and Naqvi Imran Haider, Investigating Organizational Commitment as the Outcome of Job Satisfaction: A Study of Banking Sector of Pakistan, International Journal of Learning and Development, Vol. 2, (4), 2012

[49] Raymond Toga and Mjoli Q. Themba (2012).The relationship between job involvement, job satisfaction and organizational commitment among lower-level employees at a motor-car manufacturing company in East London, South Africa

[50] Stewart M. Susan, Mark N. Bing, Melissa L. Gruys and Michael C. Helford, Men, Women, and Perceptions of Work Environments, Organizational Commitment, and Turnover Intentions. Journal of Business and Public Affairs Vol 1 (1), 2007

[51] Stewart M. Susan, Mark N. Bing, Melissa L. Gruys and Michael C. Helford (2007), Men, Women, and Perceptions of Work Environments, Organizational Commitment, and Turnover Intentions. Journal of Business and Public Affairs Vol 1 (1), 2007

[52] Stewart M. Susan, Mark N. Bing, Melissa L. Gruys and Michael C. Helford (2007), Men, Women, and Perceptions of Work Environments, Organizational Commitment, and Turnover Intentions. Journal of Business and Public Affairs Vol 1 (1), 2007

[53] Clayton Bruce, Stanley Petzall, Barbara Lynch and Julie Margret (2007), an Examination of the Organisational Commitment Of Financial Planners, International Review of Business Research Papers, Vol.3 No.1. March 2007, Pp. $60-72$

[54] Labatmediene Lina, Individual correlates of organizational commitment and intention to leave the organization, Baltic Journal of Management, Vol. 2 (2), 2007, 196-212

[55] Deprez Jana, Herman Van den Broeck, Eva Cools and Dave Bouckenhoooghe Gender Differences in Commitment to Change: Impacted By Gender? Working Paper 2012

[56] Weiss, H. M, and Cropanzano, R. Affective events theory, A theoretical discussion of the structure, causes, and consequences of affective experiences at work. In B. M. Staw and L. L. Cummings (Eds.), Research in organizational behavior, 1996 (1-74). Greenwich, CT, JAI Press.

[57] Kanchana, P.N \& Panchanatham,N, “The Influence of Demographic Factors on Organisational Commitment”, International Journal of Exclusive Management Research, 2 (5), 2012, 1-13.

[58] Luchman, J. N., Kaplan, S. A., and Dalal, R. S. Getting older and getting happier with work: An information-processing explanation. Social Indicators Research, 108(3), 2012, 535-552.

[59] Anari Nahid Naderi, Teachers: emotional intelligence, job satisfaction, and organizational commitment, Journal of Workplace Learning, 24 (4), 2012, 256-269

[60] Iqbal Adnan, An Empirical Assessment of Demographic Factors, Organizational Ranks and Organizational Commitment, International Journal of Business and Management, 5, (3), 2010, 16-27

[61] Chen, L. T., Chen, C. W., \& Chen, C. Y. (2010). Are educational background and gender moderator variables for leadership, satisfaction and organizational commitment? African Journal of Business Management, 4(2), 248-261

[62] Bakan İsmail, Tuba Büyükbeşe, and Burcu Erşahan, An Investigation of Organizational Commitment and Education Level among Employees, International Journal of Emerging Sciences, 1(3), 2011, 231-245

[63] Keramatia Mohammad Ali, Mohammad Sadegh Horria and Seyed Hamid Reza Afzalipoorb, A study on effects of personal characteristics on organizational commitment, Management Science Letters 3, 2013, 345-350

[64] (a) United Republic of Tanzania (URT) National Examinations Council of Tanzania. (NECTA, 2011). Examination results-Statistics for October 2010 results

[64] (b) United Republic of Tanzania (URT), National Examinations Council of Tanzania. (NECTA, 2013). Examination resultsStatistics for October 2012 results

[65] Weiss, D. J., Dawis, R. V., England, G. W., and Lofquist, L. H.. Manual for the Minnesota Satisfaction Questionnaire. Minneapolis: University of Minnesota, 1967

[70] White Angela Paige, An Examination of Virginia Soil and Water Conservation District Employee Job Satisfaction, Doctoral Diss. Virginia Polytechnic Institute and State University, 2008

[71] Yammarino FJ; Skinner SJ and Childers TL. Understanding mail survey response behavior. Public Opinion Quarterly, 55, 1991, 613-619.

[72] Weiss, D. J., Dawis, R. V., England, G. W., \& Lofquist, L. H.. Manual for the Minnesota Satisfaction Questionnaire. Minneapolis: University of Minnesota, 1967

[73] Sekaran, U. Research Methods for Business: A Skill-building Approach (4thed.). New York: (John Wiley and Sons 2005) 
[74] Meyer, J. and Allen, N. Commitment in the Workplace: Theory, Research and Application. London: (Sage (1997)

[75] Meyer, J. and Allen, N. Commitment in the Workplace: Theory, Research and Application. London: (Sage 1997)

[76] Fields, D.L., Taking the Measure of Work, (Sage Publications, Thousand Oaks, CA. 2002)

[77] Fields, D.L., Taking the Measure of Work, (Sage Publications, Thousand Oaks, CA. 2002)

[78] Allen, N.J. and Meyer, J.P. The measurement and antecedents of affective, continuance and normative commitment to the organization. Journal of Occupational Psychology, 63, 1990, 1-18.

[79] Sekaran, U. Research Methods for Business: A Skill-building Approach (4thed.). New York: (John Wiley and Sons 2005)

[80] Walsh Marie Burns, Perceived fairness of and satisfaction with Employee performance appraisal, Doctoral Diss., Louisiana State University and Agricultural and Mechanical College, (1981)

[81] Cohen, J.W. Statistical power analysis for the behavioral sciences, 2nd edition, (Hillsdale, NJ: Lawrence Erlbaum Associates 1988)

[82] Cohen, J.W. Statistical power analysis for the behavioral sciences, 2nd edition, (Hillsdale, NJ: Lawrence Erlbaum Associates 1988)

[83] Mkumbo A.K.Kitila. Teachers' Commitment to, and Experiences of, the Teaching Profession in Tanzania: Findings of Focus Group Research, International Education Studies 5, (3) 2012, 222-227

[84] O'Reilly, Charles A.; Caldwell, David F., Job choice: The impact of intrinsic and extrinsic factors on subsequent satisfaction and commitment. Journal of Applied Psychology, 65(5),1980, 559-565

[85] Samavi S.A.. Study of Relationship between Job Satisfaction and Organizational Commitment among High-School Managers. Journal of Life Sci. Biomed. 1(1), 2011, 1-3.

[86] Hashmi Maryam Saeed and Naqvi Imran Haider, Investigating Organizational Commitment as the Outcome of Job Satisfaction: A Study of Banking Sector of Pakistan, International Journal of Learning and Development, Vol. 2, (4), 2012

[87] Raymond Toga and Mjoli Q. Themba.The relationship between job involvement, job satisfaction and organizational commitment among lower-level employees at a motor-car manufacturing company in East London, South Africa, 2012

[88] Labatmediene Lina, Individual correlates of organizational commitment and intention to leave the organization, Baltic Journal of Management, 2 (2), 2007,196-212

[89] Iqbal Adnan, An Empirical Assessment of Demographic Factors, Organizational Ranks and Organizational Commitment, International Journal of Business and Management, 5, (3), 2010, 16-27

[90] Chen, L. T., Chen, C. W., \& Chen, C. Y. Are educational background and gender moderator variables for leadership, satisfaction and organizational commitment? African Journal of Business Management, 4(2), 2010, 248-261

[91] Bakan İsmail, Tuba Büyükbeşe, and Burcu Erşahan, An Investigation of Organizational Commitment and Education Level among Employees, International Journal of Emerging Sciences, 1(3), 2011, 231-245

[92] Keramatia Mohammad Ali, Mohammad Sadegh Horria and Seyed Hamid Reza Afzalipoorb, A study on effects of personal characteristics on organizational commitment, Management Science Letters 3, 2013, 345-350

[93] Anari Nahid Naderi, Teachers: emotional intelligence, job satisfaction, and organizational commitment, Journal of Workplace Learning, 24 (4), 2012, 256-269

[94] Salami Samuel O., Demographic and Psychological Factors Predicting Organizational Commitment among Industrial Workers, Anthropologist, 10(1): (2008), 31-38

[95] Salleh Rohani, Nair Mishaliny Sivadahasan, and Harun Haryanni, Job Satisfaction, Organizational Commitment and Turnover Intention: A Case Study on Employees of a Retail Company in Malaysia, World Academy of Science, Engineering and Technology issue $72,2012,316-323$

[96] Salleh Rohani, Nair Mishaliny Sivadahasan, and Harun Haryanni, Job Satisfaction, Organizational Commitment and Turnover Intention: A Case Study on Employees of a Retail Company in Malaysia, World Academy of Science, Engineering and Technology issue $72,2012,316-323$

[97] Salami Samuel O. (2008), Demographic and Psychological Factors Predicting Organizational Commitment among Industrial Workers, Anthropologist, 10(1), 2008, 31-38 